\title{
Erratum to: A geomorphological seabed classification for the Weddell Sea, Antarctica
}

Kerstin Jerosch $^{1} \cdot$ Gerhard Kuhn $^{1} \cdot$ Ingo Krajnik $^{1}$ • Frauke Katharina Scharf ${ }^{1} \cdot$ Boris Dorschel ${ }^{1}$

Published online: 25 April 2016

(C) Springer Science+Business Media Dordrecht 2015

\section{Erratum to: Mar Geophys Res \\ DOI 10.1007/s11001-015-9256-x}

In this article, the following text fragment has been included by mistake: "PANGAEA doi will be added during the review process". During the review and editing process, it was forgotten to add the right Pangaea datasets link. With this erratum, the missing Supplementary Information is supplied: doi:10.1594/PANGAEA.846871."

The online version of the original article can be found under doi:10.1007/s11001-015-9256-x.

Kerstin Jerosch

kerstin.jerosch@awi.de

1 Alfred Wegener Institute, Bremerhaven, Germany 